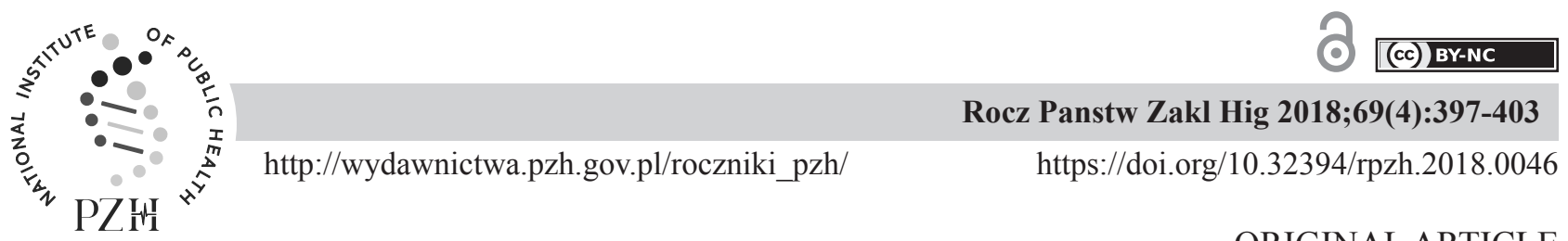

ORIGINAL ARTICLE

\title{
SELECTED ANTI-HEALTH BEHAVIOURS AMONG WOMEN WITH OSTEOPOROSIS
}

\author{
Ewa Mędrela-Kuder', Karolina Szymura ${ }^{1}$
}

${ }^{1}$ University of Physical Education, Department of Health Protection, al. Jana Pawła II 78, 31-571 Krakow, Poland

\begin{abstract}
Background. In the prevention of osteoporosis and its treatment, it is important to prevent bone loss by reducing the occurrence of factors determining human health, which reduce the risk of osteoporosis, such as health behaviors. Objective. Characteristics of modifiable risk factors predisposing to osteoporosis, such as: low intake of calcium and vitamin $\mathrm{D}_{3}$ in the diet, smoking, coffee and alcohol abuse.

Material and methods. The study involved 400 women aged 50-74 who are suffering from osteoporosis T-score $<-2.5 \mathrm{SD}$ and those who are healthy T-score $>-1 \mathrm{SD}$, living in the Malopolska voivodeship. A questionnaire was used to conduct the study.

Results. More than half of the respondents with osteoporosis (51\%) were drinking coffee several times a day. In the healthy group, the majority of respondents $(77.5 \%)$ were drinking coffee once a day. None of the healthy subjects drank more than two units of alcohol per day, and in the group of patients $2 \%$ of respondents declared consumption of more than two units of alcohol every day. Women with osteoporosis were more likely to smoke cigarettes and declared more frequent intake of calcium-containing products than healthy women. In the group of 200 examined women suffering from osteoporosis, $26.5 \%$ daily consumed milk, and $21.5 \%$ included this product three times a week in their diet. Healthy women did not drink milk every day. One-third (30.5\%) of women with osteoporosis provided the daily recommended dose of calcium by consuming a slice of cheese. None of the healthy women examined included yellow cheese in daily meals, but only once (22\%) or three times $(26.5 \%)$ a week.

Conclusions. It is important to introduce a health education in order to increase knowledge about the risk factors of osteoporosis, including the principles of proper nutrition with an emphasis on calcium and vitamin $\mathrm{D}_{3}$ intake.
\end{abstract}

Key words: osteoporosis, anti-health behaviors, risk factors, calcium, vitamin $D_{3}$, diet

\section{STRESZCZENIE}

Wprowadzenie. W profilaktyce osteoporozy i jej leczenia znaczenie ma zapobieganie utracie masy kostnej poprzez ograniczenie występowania czynników determinujących zdrowie człowieka, które zmniejszają ryzyko wystąpienia osteoporozy, takich jak zachowania zdrowotne.

Cel badań. Charakterystyka modyfikowalnych czynników ryzyka predysponujących do wystąpienia osteoporozy, takich jak: mała podaż wapnia i witaminy $\mathrm{D}_{3} \mathrm{w}$ diecie, palenie papierosów, nadużywanie kawy i alkoholu. Material i metody. Badaniami objęto 400 kobiet w wieku 50-74 lata, które chorują na osteoporozę T-score $<-2,5$ SD oraz te, które są zdrowe T-score>-1 SD, mieszkające w województwie małopolskim. Do przeprowadzenia badania wykorzystano kwestionariusz ankiety.

Wyniki. Ponad połowa badanych z osteoporozą (51\%) piła kawę kilka razy dziennie. Natomiast w grupie zdrowych większość ankietowanych (77,5\%) piła kawę raz dziennie. Żadna ze zdrowych badanych nie piła więcej niż dwie jednostki alkoholu dziennie, a w grupie chorych $2 \%$ ankietowanych deklarowała spożycie ponad dwóch jednostek alkoholu codziennie. Kobiety z osteoporozą częściej paliły papierosy oraz deklarowały częstsze spożycie produktów zawierających wapń, niż kobiety zdrowe. W grupie 200 badanych kobiet chorujących na osteoporozę $26,5 \%$ codziennie spożywała mleko, a $21,5 \%$ uwzględniła ten produkt trzy razy w tygodniu w swoim żywieniu. Kobiety zdrowe nie piły mleka codziennie. Jedna trzecia (30,5\%) kobiet z osteoporozą zapewniała codzienną zalecaną dawkę wapnia poprzez konsumpcję plastra sera żółtego. Żadna z badanych kobiet zdrowych nie uwzględniła sera żółtego w codziennych posiłkach, a jedynie raz (22\%) lub trzy razy $(26,5 \%)$ w tygodniu.

Corresponding author: Ewa Mędrela-Kuder, Department of Health Protection, University of Physical Education, 31-571 Kraków, al. Jana Pawła II 78, tel. 0126831 575,e-mail: ewa.medrela@awf.krakow.pl

(C) Copyright by the National Institute of Public Health - National Institute of Hygiene 
Wnioski. Istotnym jest wprowadzenie edukacji zdrowotnej z zakresu czynników ryzyka osteoporozy, ze szczególnym uwzględnieniem prawidłowego żywienia z naciskiem na spożycie wapnia i witaminy D3.

Słowa kluczowe: osteoporoza, zachowania antyzdrowotne, czynniki ryzyka, wapń, witamina $D_{3}$, dieta

\section{INTRODUCTION}

Osteoporosis (OP - osteoarthritis) as a chronic metabolic disease of the skeletal system, characterized by, as defined in 1993, the so-called Concensus Development Conference of the World Health Organization, reduced mineral density and disturbances in microarchitecture of bone tissue, consequently leads to an increased risk of fractures and a deterioration of the quality of life $[2,8,9]$.

The etiopathogenesis of osteoporosis, which according to WHO is a socio-civilization disease, is not yet fully known, which indicates its complex character [11]. Taking into account all risk factors for osteoporosis in the diagnosis, the occurrence of low-energy fracture may be rejected. On the basis of epidemiological studies, groups of factors predisposing to osteoporosis were distinguished, including such components as: demographic and genetic, environmental, procreative status, diet, psychoactive substances, long-term medicine treatment, co-morbidities, surgical operations and previous low energy fractures [5].

A diet low in calcium and vitamin $\mathrm{D}_{3}$, high consumption of caffeine and the use of psychoactive substances affect the loss of bone mass. Smoking is a serious predisposing factor for osteoporosis. The risk of developing osteoporosis in women increases menopause, which causes many changes in the body.

Natural menopause and menopause resulting from a surgical operation cause a decrease and, consequently, complete cessation of estrogen production. As a result of estrogen deficiency, there is a decrease in the absorption of calcium in the gastrointestinal tract, and as a result, a reduction in bone mass. In postmenopausal women, within 5-7 years, up to $20 \%$ decrease in bone loss may occur. Another factor that reduces the absorption of calcium from the gastrointestinal tract is also the lowering of the level of receptors for vitamin $\mathrm{D}_{3}$ in the target organs $[5,18]$. One of the factors determining the occurrence of osteoporosis is an incorrect diet [19].

The aim of the study was to characterize modifiable risk factors predisposing to osteoporosis, such as low supply of calcium and vitamin $\mathrm{D}_{3}$ in the diet, smoking, coffee and alcohol abuse.

\section{MATERIAL AND METHODS}

The study included 400 women aged 50 to 74 years in Malopolska Medical Center in Krakow. Two groups of 200 women were distinguished among the respondents. Group I consisted of patients diagnosed with osteoporosis
[T-score $<-2.5 \mathrm{SD}$ ]. Age in the group of patients was on average $64.11 \pm 7.06$ years. Group II included healthy people who did not develop osteoporosis [T-score $>-1 \mathrm{SD}$ ]. The average age of healthy women was $62.79 \pm 7.75$ years. All healthy women lived in towns over 70,000. residents. In the group of patients, the place of residence was varied, although the majority $(73 \%)$ were still residents of cities over 70,000. residents. In connection with the above, $14 \%$ of the remaining subjects with osteoporosis were women living in the village, $9 \%$ in a small town and $5 \%$ in the city up to 70,000. residents. Most women with osteoporosis had secondary education (32\%). In the group of patients, $19 \%$ of respondents completed the primary education, while $22 \%$ of women had basic vocational education. Almost one third of the patients (27\%) graduated from university. Education among healthy women was as follows: $57 \%$ had completed primary schools, $24 \%$ high schools and 19\% had higher education. Among women, a voluntary, anonymous questionnaire was conducted, which concerned the diet and the use of psychoactive substances.

\section{RESULTS}

Surveyed with osteoporosis declared more frequent intake of calcium-containing products than healthy women. Among women suffering from osteoporosis, $26.5 \%$ daily consumed milk, and $21.5 \%$ included this product three times a week in the diet (statistically significant). Over $90 \%$ of healthy subjects did not include buttermilk, bonny clabber and cocoa in their diet (statistically significant). One third (30.5\%) of women with osteoporosis provided the daily recommended dose of calcium by consuming a slice of cheese (statistically significant).

Among the respondents with osteoporosis, $42 \%$ daily varied their diet with yogurts, while healthy women less often chose this product (28\%) (statistically significant). In both groups, the most preferred source of calcium was skinny cottage cheese and eggs. The subjects, in both groups, included eggs in the diet three times a week (50\% WO, 67\% HW) (statistically significant). Among the respondents of both groups, there was an increase in the consumption of wholewheat bread, with a significant dominance in the group of healthy women (99\%) (statistically significant).

Almost all healthy respondents (99\%) consumed fresh fruit every day, and in the group of patients $62 \%$ consumed fruit once a day (statistically significant). In the weekly diet, the examined included green vegetables $(59.5 \% \quad \mathrm{HW}, \quad 51 \% \quad \mathrm{WO})$ (statistically significant) (Table 1). 
Table 1. Characteristics of current consumption of calcium-containing products: milk, dairy, fruit and vegetables, bread and poultry



${ }^{*} \mathrm{p}<0.05$ - significant effect, ${ }^{* *} \mathrm{p}<0.01$ - highly significant effect, ${ }^{* * *} \mathrm{p}<0.001$ - extremely significant effect, $\mathrm{Ch}^{2}-$ nonparametric test, $\mathrm{Df}$ - degrees of freedom, bold - statistically significant 
Most often, women with osteoporosis chose fish once a week: sardines (12.5\%), mackerel (48\%). Salmon consumption was declared several times a month by $24 \%$ of women with osteoporosis, and by $20 \%$ of healthy respondents once a week. Two-thirds of women with osteoporosis alternately used butter and margarine in a weekly diet. On the other hand, the remainding part of the respondents do not opt for these products (statistically significant) (Table 2 ).

Table 2. Characteristics of consumption of products containing vitamin $\mathrm{D}_{3}$ : selected fish, liver, butter and margarine

\begin{tabular}{|c|c|c|c|c|c|c|c|c|}
\hline \multirow{2}{*}{\multicolumn{2}{|c|}{$\begin{array}{c}\text { Products containing } \\
\text { vitamin } \mathrm{D}_{3}\end{array}$}} & \multicolumn{2}{|c|}{$\begin{array}{l}\text { Women with } \\
\text { osteoporosis } \\
\text { (WO) }\end{array}$} & \multicolumn{2}{|c|}{$\begin{array}{c}\text { Control group } \\
\text { (HW) }\end{array}$} & \multirow{6}{*}{$\begin{array}{l}\mathrm{Chi}^{2} \\
39.09\end{array}$} & \multirow{6}{*}{$\begin{array}{c}\text { Df } \\
\\
\\
5\end{array}$} & \multirow{6}{*}{$\begin{array}{c}\text { P-value } \\
\mathrm{p}<0.0001 * * *\end{array}$} \\
\hline & & $\mathrm{N}$ & $\%$ & $\mathrm{~N}$ & $\%$ & & & \\
\hline \multirow[t]{4}{*}{ salmon } & once a week & 7 & 3.5 & 40 & 20 & & & \\
\hline & several times a month & 48 & 24 & 36 & 18 & & & \\
\hline & less frequently & 8 & 4 & 16 & 8 & & & \\
\hline & at all & 127 & 63.5 & 108 & 54 & & & \\
\hline \multirow[t]{4}{*}{ sardines } & once a week & 25 & 12.5 & 10 & 5 & \multirow{4}{*}{105.57} & \multirow{4}{*}{5} & \multirow{4}{*}{$\mathrm{p}<0.0001 * * *$} \\
\hline & several times a month & 16 & 8 & 36 & 18 & & & \\
\hline & less frequently & 3 & 1.5 & 72 & 36 & & & \\
\hline & at all & 146 & 73 & 82 & 41 & & & \\
\hline \multirow[t]{4}{*}{ mackerel } & once a week & 96 & 48 & 68 & 34 & \multirow{4}{*}{71.39} & \multirow{4}{*}{5} & \multirow{4}{*}{$\mathrm{p}<0.0001 * * *$} \\
\hline & several times a month & 39 & 19.5 & 30 & 15 & & & \\
\hline & less frequently & 1 & 0.5 & 56 & 28 & & & \\
\hline & at all & 52 & 26 & 46 & 23 & & & \\
\hline \multirow[t]{5}{*}{ herring } & once a week & 14 & 7 & 10 & 5 & \multirow{5}{*}{65.43} & \multirow{5}{*}{5} & \multirow{5}{*}{$\mathrm{p}<0.0001 * * *$} \\
\hline & several times a month & 35 & 17.5 & 28 & 14 & & & \\
\hline & once a month & 12 & 6 & 21 & 10.5 & & & \\
\hline & less frequently & 4 & 2 & 59 & 29.5 & & & \\
\hline & at all & 134 & 67 & 82 & 41 & & & \\
\hline \multirow[t]{4}{*}{ tuna } & once a week & 28 & 14 & 12 & 6 & \multirow{4}{*}{73.72} & \multirow{4}{*}{5} & \multirow{4}{*}{$\mathrm{p}<0.0001 * * *$} \\
\hline & several times a month & 30 & 15 & 28 & 14 & & & \\
\hline & less frequently & 7 & 3.5 & 72 & 36 & & & \\
\hline & at all & 128 & 64 & 80 & 40 & & & \\
\hline \multirow[t]{3}{*}{ liver } & several times a month & 34 & 17 & 0 & 0 & \multirow{3}{*}{83.71} & \multirow{3}{*}{5} & \multirow{3}{*}{$\mathrm{p}<0.0001 * * *$} \\
\hline & less frequently & 41 & 20.5 & 12 & 6 & & & \\
\hline & at all & 110 & 55 & 186 & 93 & & & \\
\hline \multirow[t]{4}{*}{ margarine } & daily & 72 & 36 & 56 & 28 & & & \\
\hline & 3 times a week & 50 & 25 & 18 & 9 & & 5 & 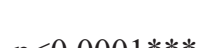 \\
\hline & several times a month & 0 & 0 & 30 & 15 & 50.91 & 3 & $p<0.0001$ \\
\hline & at all & 74 & 37 & 96 & 48 & & & \\
\hline butter & daily & 70 & 35 & 83 & 41.5 & & & \\
\hline & 3 times a week & 55 & 27.5 & 16 & 8 & $5 ? 02$ & 5 & $\mathrm{p}<0.0001^{* * *}$ \\
\hline & several times a month & 4 & 2 & 30 & 15 & 32.02 & $J$ & \\
\hline & at all & 62 & 31 & 71 & 35.5 & & & \\
\hline
\end{tabular}

${ }^{*} \mathrm{p}<0.05$ - significant effect, ${ }^{* *} \mathrm{p}<0.01$ - highly significant effect, $* * * \mathrm{p}<0.001$ - extremely significant effect, Chi2 - nonparametric test, $\mathrm{Df}$ - degrees of freedom, bold - statistically significant

Among the surveyed women with osteoporosis, more than half consumed coffee several times a day. Coffee was drunk once a day by $38.5 \%$ of the respondents. The control group had significantly lower coffee consumption (Table 3). 
Table 3. Characteristics of selected anti-health behaviors conducive to osteoporosis: consumption of coffee and alcohol, smoking cigarettes, slimming treatments

\begin{tabular}{|c|c|c|c|c|c|c|c|}
\hline $\begin{array}{c}\text { Anti-health behaviors conducive to } \\
\text { osteoporosis }\end{array}$ & $\begin{array}{r}V \\
\text { oster }\end{array}$ & $\begin{array}{l}\text { with } \\
\text { s (WO) }\end{array}$ & Contr & up $(\mathrm{HW})$ & $C h i^{2}$ & Df & P-value \\
\hline Coffee consumption & $\mathrm{N}$ & $\%$ & $\mathrm{~N}$ & $\%$ & \multirow{5}{*}{66.70} & \multirow{5}{*}{3} & \multirow{5}{*}{$\mathrm{p}<0.0001 * * *$} \\
\hline Several times a day & 102 & 51 & 30 & 15 & & & \\
\hline Once a day & 77 & 38.5 & 155 & 77.5 & & & \\
\hline Less frequently & 4 & 2 & 2 & 1 & & & \\
\hline At all & 17 & 8.5 & 13 & 6.5 & & & \\
\hline Alcohol consumption & $\mathrm{N}$ & $\%$ & $\mathrm{~N}$ & $\%$ & \multirow{3}{*}{4.04} & \multirow{3}{*}{1} & \multirow{3}{*}{$\mathrm{p}=0.0444^{*}$} \\
\hline Yes & 4 & 2 & 0 & 0 & & & \\
\hline No & 196 & 98 & 200 & 100 & & & \\
\hline Smoking & $\mathrm{N}$ & $\%$ & $\mathrm{~N}$ & $\%$ & \multirow{5}{*}{126.31} & \multirow{5}{*}{3} & \multirow{5}{*}{$\mathrm{p}<0.0001^{* * *}$} \\
\hline Yes & 75 & 37.5 & 7 & 3.5 & & & \\
\hline Yes, occasionally & 15 & 7.5 & 0 & 0 & & & \\
\hline Smoked in the past & 39 & 19.5 & 16 & 8 & & & \\
\hline No & 71 & 35.5 & 177 & 88.5 & & & \\
\hline Smokers nearby & $\mathrm{N}$ & $\%$ & $\mathrm{~N}$ & $\%$ & \multirow[t]{3}{*}{0.50} & \multirow[t]{3}{*}{1} & \multirow[t]{3}{*}{$\mathrm{p}=0.4799$} \\
\hline Yes & 117 & 58.5 & 110 & 55 & & & \\
\hline No & 83 & 41.5 & 90 & 45 & & & \\
\hline Slimming treatments & $\mathrm{N}$ & $\%$ & $\mathrm{~N}$ & $\%$ & \multirow{3}{*}{3.46} & \multirow{3}{*}{1} & \multirow{3}{*}{$\mathrm{p}=0.0630$} \\
\hline Yes & 17 & 8.5 & 8 & 4 & & & \\
\hline No & 183 & 91.5 & 192 & 96 & & & \\
\hline
\end{tabular}

${ }^{*} \mathrm{p}<0.05$ - significant effect, $* * \mathrm{p}<0.01$ - highly significant effect, $* * * \mathrm{p}<0.001$ - extremely significant effect, $C$ i $\mathrm{i}^{2}$ - nonparametric test, Df - degrees of freedom, bold - statistically significant

The vast majority, $88.5 \%$ of healthy respondents, did not smoke cigarettes, while among women with osteoporosis nearly $40 \%$ of the respondents smoked cigarettes regularly. Less than $10 \%$ of women with osteoporosis declared using slimming treatments several times, and in the healthy group only $4 \%$ of respondents declared it.

\section{DISCUSSION}

The indication of factors predisposing to reduction of bone mineral density, as well as the analysis of selected modifiable risk factors for osteoporosis, contribute to the improvement of the quality of life of patients with osteoporosis and to improvement of the prophylaxis of this disease.

Nutritional behaviors are one of the main modifiable factors that determine the correct bone mineral value, affecting the peak bone mass. Sidor et al. [16] in a study conducted in a group of women aged 20-30 years, showed that the vast majority of respondents $(89 \%)$ declared lower energy value of the diet than the due energy demand at this age. Proper nutrition is a basic element in the prevention of osteoporosis in women in the perimenopausal period. The analysis of nutritional recommendations in the field of osteoporosis prophylaxis developed by Platta [14] shows that the body should be provided with all necessary nutrients that have an impact on bone structure and bone mineral state. Prevention of osteoporosis is associated with supplementation with calcium, vitamin $\mathrm{D}$, magnesium and other mineral components Nutrient deficiency is related to, among others, the syndrome of impaired absorption and abnormal digestion, phases of rapid growth, pregnancy, breastfeeding period, immobility period. According to Shea et al. [15], it also has a place during dietary restrictions during slimming treatments, in a vegetarian diet, anti-atherosclerotic diet or in parenteral nutrition. The authors pay attention to rational nutrition, especially at the age of 50-55, where the proportion of calcium to phosphorus should be in the ratio of 1:1.

This paper shows that the current consumption of products containing calcium, especially milk and its products, was higher in the group of women with osteoporosis, although not sufficient in relation to the standards recommended by the Institute of Food and Nutrition in Warsaw [20]. It should be noted 
that women with osteoporosis declared a change in diet after diagnosing the disease. Wawrzyniak et al. [17] conducted research among 100 women, aged 51-70. The authors showed that only $8 \%$ of women with osteoporosis changed the diet after diagnosis, increasing the amount of dairy products in it. Also Ciesielczuk et al. [2] studied a group of 150 randomly selected people over 50 years of age. The majority of respondents $60.7 \%$ had osteoporosis. The authors noticed that diagnosed women were more aware of the risk of osteoporosis. The respondents knew that consuming dairy products has a positive effect on bone mineral density.

In own research, as in the assessment of anti-health behaviors among women with osteoporosis carried out by Mędrela-Kuder [13], it was shown that the majority of respondents did not know products rich in calcium.

In the diet, healthy women did not take into account the consumption of milk every day, while almost one third of the patients with osteoporosis daily drank a glass of milk. Also sick women more often chose products such as buttermilk, bonny clabber or cocoa, thus providing the right amount of calcium.

In this study, we tried to assess whether the subjects ensure the recommended daily norm by the Food and Nutrition Institute (IZZŻ) in Warsaw in addition to other calcium-rich products, by using a slice of cheese [20]. None of the healthy women included cheese in their daily meals; only once or three times a week. In contrast, one-third of respondents with osteoporosis consumed this product daily.

In our study, consumption of ripening cheeses (yellow cheeses) was found among women with osteoporosis at the level of the daily norm recommended by the Institute of Food and Nutrition in Warsaw in addition to other products rich in calcium [20]. It should be noted that these cheeses are, however, rich in fats limiting the absorption of calcium and it is not advisable to consume them in larger quantities.

A significant source of calcium are fresh green leafy vegetables and fruits. Our own studies also included the intake of these vegetables and fruits. In the control group, the vast majority of respondents (99\%) daily included fresh fruit in their diet. Among the ill women, the consumption of fresh fruit was lower $(60 \%)$ than in the healthy group.

Another source of calcium is poultry meat. According to own research, poultry is consumed in both groups, usually three times a week (almost 65\% of respondents). The osteoporotic subjects aimed to regularly choose dairy products and vegetables and fruits, thanks to which they followed the dietary recommendations for the prevention of osteoporosis.

In our research, it has been noticed that the inclusion of products such as margarine or powdered milk once a week in the diet, and the use of butter or margarine for bread once in a while, is insufficient to provide an adequate level of vitamin $\mathrm{D}_{3}$ (both groups). Therefore, supplements of this vitamin should be taken.

Dawson-Huges et al. [4] in addition to studying the effect of calcium on bone mineral density, analyzed the effect of vitamin $\mathrm{D}_{3}$ on the development of osteoporosis. The authors' research shows that vitamin $\mathrm{D}_{3}$ increases the absorption of calcium from the gastrointestinal tract, reduces the concentration of parathyroid hormone in the blood and increases the bone mineral density. Also Lips et al. [12] on the basis of the review of the work that concerned the supplementation with vitamin $\mathrm{D}_{3}$, found that its administration together with calcium brings great effects in the elderly, who have been shown to be deficient in vitamin $\mathrm{D}_{3}$ and have too little calcium supply.

Another aspect was anti-health habits, which include the use of psychoactive substances such as: nicotine, alcohol and caffeine. According to Jutberger [10], the impact of tobacco on bone is multi-dimensional. It causes a reduction in BMI, it directly affects bone cells by exposure to cadmium, shortens estrogen survival time and increases their excretion. In addition, it dysregulates thyroid and parathyroid glands, stimulates the adrenal cortex to ACTH secretion (adrenocorticotropin), increases blood cortisol level and, most importantly, smoking significantly increases the risk of major osteoporotic fractures, including fractures of the proximal femur.

In our study, it was shown that the majority of healthy women, $89 \%$, did not smoke in the past. Patients with osteoporosis who have smoked in the past or are doing it now are exposed to one of the factors that reduce bone mass. It should be noted that in order to reduce the negative effects of cadmium contained in cigarettes, first of all, do not smoke and avoid being around smokers.

In the American fifteen-year observation of BMD values by Cauley et al. [1], in the large-scale study of SOF (The Study of Osteoporotic Fractures), smoking and glucocorticosteroid therapy were considered the biggest threat to reduce bone mineral density.

According to Gallagher et al. [6], eating crustaceans from the New England coast or the Great Lakes, whose waters have a high concentration of cadmium should be reduced or even avoided.

Alcohol, alongside nicotine, is a serious threat to the proper functioning of the body. In excessive amounts it can contribute to the inhibition of bone and cartilage production due to the negative calcium balance. In this study, all women surveyed stated alcohol abstinence.

Another risk factor for osteoporosis, in addition to alcohol abuse and smoking, is excessive consumption of caffeine, especially in coffee, but also in tea, chocolate, cocoa, cola beverages and energy drinks. Hallstrom et 
al. [7] in their studies showed that consumption of 330 $\mathrm{mg}$ of caffeine equivalent to 4 cups of coffee or more may increase the risk of osteoporosis, especially in women with low calcium intake.

Half of the women with osteoporosis drank coffee several times a day. It is worth noting that the vast majority of healthy women surveyed, drank one cup of coffee a day.

\section{CONCLUSIONS}

1. Women with osteoporosis declared that they changed their diet after diagnosing the disease.

2. Eating habits, such as a diet low in calcium or vitamin $\mathrm{D}_{3}$, in the group of healthy women may become the cause of osteoporosis.

3. It is important to introduce a health education program in order to increase knowledge about the risk factors of osteoporosis, including the principles of proper nutrition and avoidance of psychoactive substances.

\section{Conflict of interest}

The authors declare no conflict of interest.

\section{REFERENCES}

1. Cauley J.A., Lui L.Y., Barnes D.: Successful skeletal aging: a marker of low fracture risk and longevity. The Study of Osteoporotic Fractures (SOF). J Bone Miner Res 2009;24:134-143.

2. Ciesielczuk N., Glibowski P., Szczepanik J.: Awareness of factors affecting osteoporosis obtained from a survey on retired Polish subjects. Rocz Panstw Zakl Hig 2014;65(2):147-153.

3. Compston J., Cooper A., Bowrling C.: National Osteoporosis Guideline Group (NOGG). Diagnosis and management of osteoporosis in postmenopausal women and older men in the UK. Maturitas 2013;75:392-396.

4. Dawson-Huges B.: Osteoporosis. [W] Shils M.E., Shike M., Ross A.C., Caballero B., Cousins R.J., Modern Nutrition in health and disease. Filadelfia: Lippincott Williams and Wilkins 2008;1339-1359.

5. Edwards B.J., Brooks E.R., Langman C.B.: Osteoporosis screening of postmenopausal women in the primary care setting: A case-based approach. Gender Medicine 2004; 1 (2):70-85.

6. Gallagher C.M., Kovach J.S., Meliker J.R.: Urinary cadmium and osteoporosis in U.S. Women $>$ or $=50$ years of age. Environ Health Perspect 2008;116(10):13381343.

7. Hallstrom H., Wolk A., Glynn A., Michaelsson K.: Coffee, tea and caffeine consumption in relation to osteoporotic fracture risk in a cohort of Swedish women. Osteoporos Int. 2006;17(7):1055-1064.

8. Hernlund E., Svedbom A., Ivergard M., Compston J.: A report prepared in collaboration with the International Osteoporosis Foundation (IOF) and the European Federation of Pharmaceutical Industry Associations (EFPIA). Arch Osteoporos 2013; 8:136.

9. Johnell O., Kanis J.A.: An estimate of the worldwide prevalence and disability associated with osteoporotic fracture. Osteoporos. Int. 2006;17:1726-1733.

10. Jutberger H., Lorentzon M., Barret-Connor E.: Smoking predicts incident fractures in elderly men: $\mathrm{Mr}$ OS Sweden. J Bone Miner Res 2010;25:1010-1016.

11. Koligat D., Leszczyński P., Pawlak-Buś K., Koligat A., Zaprutko T., Kus K., Paczkowska A., Ratajczak P., Nowakowska E.: Impact of chronic diseases (osteoporosis and diabetes) on Health Related Quality-of-Life - a pilot study. Nowiny Lekarskie 2012;81(2):122-128 (in Polish).

12. Lips P., Bouillon R., van Schoor N.M.: Reducing fracture risk with calcium and vitamin D, Clin. Endocrin. 2009;124:400-406.

13. Mędrela-Kuder E.: Unhealthy behaviour patterns encouraging the development of osteoporosis. Rocz Panstw Zakl Hig 2009;60(2):181-184.

14. Platta A.: The role of the diet in the prophylaxis and treatment of the osteopenia and osteoporosis of women. The Scientific Journal of Gdynia Maritime University 2014;86:16-28 (in Polish).

15. Shea B., Wells G., Cranney A.: Calcium supplementation on bone loss in postmenopausal women. Cochrane Database Syst Rev 2007;18:1.

16. Sidor P., Głąbska D., Włodarek D.: Analysis of the diet are factors contributing to the future osteoporosis risk in young Polish women. Rocz Panstw Zakl Hig 2016;67(3): 279-285.

17. Wawrzyniak A., Klimczyk P., Woźniak A., Anyżewska A., Leonkiewicz M.: Assessment of differences in nutrients consumption In women diagnosed with osteoporosis as compared to a health control group. Rocz Panstw Zakl Hig 2017;68(2):143-149.

18. Włach-Tkaczuk J., Sobstyl M., Jakiel G.: Osteoporosis - clinical picture, risk factors and diagnostics. Prz Menopauzalny 2010;2:113-117 (in Polish).

19. Włodarek D.: The role of diet in the prevention of osteoporosis. Endokrynol. Otył. Zab. Przem. Mat. 2009;5(4):245-253 (in Polish).

20. Wojtasik A., Jarosz M., Stoś K.: Mineral ingredients, Jarosz M. [red.]. Nutritional standards for the population of Poland. Wyd. Instytut Żywności i Żywienia im. Prof. Szczygła, Warszawa, 2017, 204-206.

Received: 21.11.2017

Accepted: 15.10.2018

This article is available in Open Access model and licensed under a Creative Commons Attribution-Non Commercial 3.0.Poland License (CC-BY-NC) available at: http://creativecommons.org/licenses/by-nc/3.0/pl/deed.en 